\title{
Kultttuuriperintökysymykset kokosivat tutkijoita ja taiteilijoita Helsingin yliopiston tutkijakollegiumiin
}

\author{
"No such thing as heritage?" - From basic assumptions and constructs to \\ reconceptualizations -konferenssi Helsingissä 4.-6. maaliskuuta
}

\section{Konferenssiraportti}

\section{Oona Simolin}

$\mathrm{H}$ elsingin yliopiston tutkijakollegiumin (HCAS) järjestämä konferenssi "No such thing as heritage?" - From basic assumptions and constructs to reconceptualizations pidettiin 4.-6.3. Helsingin yliopistolla. Meneillään olevan pandemian takia ajankohta oli varsin onnekas ja lähes viimeinen mahdollinen ennen poikkeusjärjestelyitä. Monia eri tieteenaloja edustavia puhujia saapui paikalle 25 henkeä ympäri maailman, ja kaikille avointa ja ilmaista konferenssia oli mahdollista seurata osittain myös etäyhteyksien välityksellä. Ohjelmassa oli sekä kulttuuriperintöä kriittisesti tarkastelevia esitelmiä että itse kriittisen kulttuuriperinnön tutkimuksen kenttää ja sen vaikutuksia pohtivia papereita. Oman lisänsä ohjelmaan toivat perinteiseen musiikkiin ja rituaaleihin pohjautuvat taiteelliset esitykset, jotka heijastelivat hienosti yksilöllisen itseilmaisun ja kollektiivisen kulttuurin tutkimiseen liittyviä ydinkysymyksiä.

Konferenssin nimi perustuu kulttuuriperinnön tutkija Laurajane Smithin tunnettuun teokseen Uses of Heritage (2006). Smith (Australian National University) avasikin itseoikeutetusti tapahtuman keynote-luennollaan "Cultural Heritage: Politics, Nationalism and Populism", joka käsitteli kulttuuriperinnön poliittisia ulottuvuuksia. Hän toi esiin tutkimuksessaan tekemänsä huomion siitä, miten kulttuuriperintökohteissa vieraillessaan kävijöillä on usein tapana vahvistaa olemassa olevia uskomuksiaan ja maailmankuvaansa ennemmin kuin haastaa niitä. Nämä käsitykset voivat tukea vallassa olevia ideologioita ja tasa-arvoa horjuttavia yhteiskunnan rakenteita. Hänen tapausesimerkissään kävijät tulkitsivat Yhdysvaltain orjuuden historiaa jopa hyväksyen, kun se yhdistyy plantaasien kautta ensimmäisiin presidentteihin ja tätä kautta suureen kansalliseen narratiiviin. Smith esitti, että kriittinen tutkimusnäkökulma voi siis ajoittain yliarvioida kävijöiden halua reflektioon ja oppimiseen.

Tapahtuman toisen päivän avannut keynote-puhuja Kristin Kuutma (Tarton yliopisto) jatkoi Smithin ja monien muiden puhujien käsittelemien aiheiden parissa. Kuutma lähestyi 
perintöpoliittisia kysymyksiä aineettoman kulttuuriperinnön käsitteen kautta. Hän tarkasteli esityksessään kriittisesti perinteellistämistä eli kulttuuristen ilmausten kuten perinteiden muuntumista kiinteiksi ja ylhäältä määritellyiksi ilmiöiksi. Esitelmä katsasti näitä prosesseja erityisesti Unescon viitekehyksessä, jossa kulttuurin jatkuvasti muuttuva olemus ja toisaalta luetteloinnin edellyttämä selkeärajaisuus aiheuttaa monenlaisia haasteita. Kolmannen konferenssipäivän avasi Suzie Thomas (Helsingin yliopisto) esityksellään, joka käsitteli Lapin synkkä kulttuuriperintö -projektia. Thomas jatkoi edellisten päivien tematiikassa ja syventyi erityisesti synkän kulttuuriperinnön (dark heritage) käsitteeseen purkaen niin synkkyyden kuin kulttuuriperinnön olemusta. Myös Thomas herätteli keskustelua siitä, ovatko yleisöt todella niin valmiita kriittiseen itsereflektioon kuin oletetaan ja toivotaan. Kysymys on oleellinen erityisesti kriittisen kulttuuriperinnön tutkimuksen vaikuttavuuden kannalta.

\section{Alkuperäiskansojen kulttuuriperintö: kriittisiä katseita}

Keskustelut kulttuuriperintöön liittyvistä valtadynamiikoista ovat käyneet kuumina sekä akateemisissa piireissä että niiden ulkopuolella. Rani-Henrik Andersson (Helsingin yliopiston tutkijakollegium) pureutui esitelmässään länsimaisen luonnonsuojelun ajatuksen ja alkuperäiskansojen luontokäsityksen väliseen jännitteeseen uusiseelantilaisen Te Awa Tupuan tapauksen kautta. Valtasuhteiden käsittelyn tiellä jatkoi Andreas Kalkunin (Helsingin yliopisto, Viron kirjallisuusmuseo) esitelmä, joka käsitteli setojen lauluperinnettä ja laulujen kääntämistä viroksi. Kalkun esitti käännösprosessin vähintäänkin kyseenalaisena ja nosti esiin etenkin 1800-luvulla yleistä tapaa ymmärtää setojen kulttuuri virolaisen valtakulttuurin muodoksi.

Alkuperäiskansojen kulttuurien määrittely valtakulttuurin kautta ja vallitsevien ideologioiden tarpeiden mukaan on alkuperäiskansojen perintöä koskevien kysymysten kovaa ydintä. Kuten Karina Lukin (Helsingin yliopisto, Itä-Suomen yliopisto) osoitti, tällä on pitkäkestoisia seurauksia. Lukin kertoi kuinka neuvostoaikana tapahtunut nenetsien folkloren sovitus vallitseviin poliittisiin olosuhteisiin elää ja voi hyvin vielä nykyäänkin. Lukinin esiin tuoma valtakulttuurin vaikutus alkuperäiskansojen ilmaisuihin resonoi hyvin Coppélie Cocqin (Helsingin yliopisto) alkuperäiskansojen digitaalisen ajan perintöä koskevan esitelmän kanssa. Cocq käsitteli arkistoja, niihin liittyviä käytänteitä ja suhteita alkuperäiskansoihin: mitä arkistot ja tallenteet sisältävät, entä mitä ne jättävät ulkopuolelle? Onnistuvatko länsimaisen maailmankatsomuksen perusteella syntyneet arkistokäytänteet tallentamaan alkuperäiskansojen kulttuuri-ilmaisujen merkitykset?

\section{Kulttuuriperintö on arvolatautunut väline}

Jo alkuperäiskansojen perintöä koskevat esitelmät toivat esiin kulttuuriperinnön poliittisen ja arvolatautuneen luonteen. Tämä näkökulma laajeni vielä kulttuuriperinnön, (kansallis) valtioiden ja politiikan yhteyksiä koskevissa papereissa. Gertjan Plets (Utrechtin yliopisto) analysoi Venäjän jälleenrakennusyrityksiä Syyrian Palmyrassa esimerkkinä pehmeän voiman käytöstä. Pletsin mukaan restaurointi-investointien tarkoituksena on kasvattaa Venäjän roolia kulttuuripolitiikan kautta.

Toisinaan tuntuu, että kulttuuria käytetään poliittisena välineenä kaikkialla. Tässä mielessä virkistävä oli Elo-Hanna Seljamaan (Tarton yliopisto) esitelmä, jossa hän tarkasteli voitonpäivän juhlintaa Tallinnassa. Folkloristina oli ilahduttavaa kuulla, että Seljamaan mukaan 
voitonpäivän traditiot ovat olleet viime vuosina jatkuvassa muutoksessa ja vernakulaarissa kulttuurissa monimuotoiset perinteet ovat levinneet eri kansanosiin. Vaikutelmani on, että juuri tämän perheissä juhlittavan päivän elämä instituutioiden määritelmien ulkopuolella mahdollistaa sen monet merkitykset. Jos juhlinta saisi virallisen aseman esimerkiksi kulttuuriperintöluetteloinnin myötä, sen monimuotoinen luonne todennäköisesti muuttuisi määritelmien taistelukentäksi.

Myös useat muut esitelmät käsittelivät kulttuuriperinnön määrittämisen ja arvottamisen haasteita. Dani Schrire (Jerusalemin heprealainen yliopisto) esitteli yleisölle ainutlaatuisen 200000 Pyhästä maasta lähetetyn postikortin kokoelman. Schrire kertoi, kuinka hänelle tarjotun kokoelman hankkiminen instituution hoiviin vaati sen arvon perustelua, missä Shrire refleksiivisesti totesi päättäneensä käyttää kulttuuriperintöä argumentaation tukena. Kokoelma päätettiin ottaa yliopistolle, mutta Schrire korosti, että sen määrittely kulttuuriperinnöksi ei argumentaatiovoimastaan huolimatta tyhjentänyt sitä monista merkityksistään. Vastaavasti Michael Dylan Foster (University of California, Davis) osoitti, kuinka japanilaisten niin sanottujen vierailevien jumalolentojen lisääminen Unescon aineettoman kulttuuriperinnön luetteloon on tuottanut eräänlaista metakulttuuria. Tämän nimikkeen alla on muun muassa kaksi hyvin erilaista riittiä, toshidon ja namagage, joita ei paikallisesti ole mielletty toisiinsa kytkeytyviksi. Niiden niputtaminen ylhäältäpäin uuden visiting deities -konseptin alle on tuottanut esimerkiksi aihetta käsitteleviä seminaareja. Näyttikin siltä, että Fosterin ajatus yksittäisten kulttuuri-ilmaisujen erojen ja ainutlaatuisuuden näkemisestä sai kannatusta yleisön keskuudessa.

\section{Teorian ja käytännön kohtaamisia}

Konferenssin tapaustutkimukset keskustelivat hyvin teoreettisempien esitelmien kanssa. Antti-Ville Kärjä Taideyliopistosta käsitteli Museoviraston ylläpitämän Elävän perinnön wikiluettelon sisältämiä musiikkiperinteitä ja kiinnitti yleisön huomion musiikkiperinteen paikallistamiseen ja toisaalta sen rajoihin. Samaista luetteloa analysoi Heidi Haapoja-Mäkelä (Helsingin yliopisto), joka tarkasteli kriittisesti sen välittämää kuvaa suomalaisesta luontosuhteesta. Ulla Savolainen (Helsingin yliopisto) puolestaan jatkoi kansoihin liittyvien representaatioiden analyysia keskittymällä Kansallismuseon näyttelyn välittämään kuvaan inkeriläisvähemmistöstä. Lopuksi Tuuli Lähdesmäki (Jyväskylän yliopisto) lähestyi eurooppalaisen identiteetin ja perinnön rakentamista Euroopan komission Eurooppalaisen kulttuuriperintötunnuksen kohteiden ja projektin dokumenttien kautta.

Tapaustutkimukset valaisivat nähdäkseni hyvin kulttuuriperintöalan toimijoiden kohtaamia haasteita. Kuinka kuvata ja esittää kulttuuri-ilmiöitä ilman niiden kivettämistä, mikä voi pahimmillaan vähentää yhteisöjen omistajuutta ja toimijuutta? Millaisia eettisiä ja määritelmällisiä kysymyksiä kulttuuriperinnön tekemiseen ja hallinnointiin liittyy? Useat teoreettisesti suuntautuneista esitelmistä pyrkivät löytämään vastauksia näihin ongelmiin. Esimerkiksi Johanna Enqvist (Helsingin yliopisto) korosti käsitteiden ja niitä ylläpitävien valtaverkostojen analyysin tärkeyttä kulttuuriperintötyössä. Mielestäni tämä on välttämätöntä sekä tutkijoille että kulttuuriperinnön harjoittajille. Frog Helsingin yliopistosta korostikin konferenssia yhteen vetävässä esitelmässään yhteistyön tarvetta kulttuuriperinnön ympärillä toimivien lukuisten tutkimusalojen ja -kenttien välillä. 
Tilaisuus päästä kuulemaan näin moninaista puhujien joukkoa oli harvinaista herkkua nopeasti kehittyvän kulttuuriperinnön tutkimuksen kentällä. Lisäksi taide-esitysten tuominen samaan tilaan esitelmien kanssa tarjosi mahdollisuuden peilata päivän paperien herättämiä ajatuksia käytäntöön. Moderneja itkuvirsiä esittänyt Emmi Kuittinen kertoi esityksensä lisäksi myös näkemyksiään viime aikoina pinnalla olleista omistajuuden kysymyksistä ja perinteen soveltamisen rajoista. Girilal Baarsin puhe puolestaan sai folkloristin hämmästelemään erilaisista kansanmusiikkiperinteistä ammentavan taiteilijan kykyä soveltaa kuulijoille merkityksellisiä kokemuksia, vaikka kulttuurinen konteksti ja kieli rajoittaa ymmärryksen mahdollisuuksia. Toivon näkeväni tulevaisuudessa lisää vastaavia tilaisuuksia, jotka tarjoavat mahdollisuuden keskustella kulttuuriperinnön eri puolista tutkijoiden, alan toimijoiden ja harjoittajien kesken.

\section{Kirjallisuus}

Smith, Laurajane. 2006. Uses of heritage. London: Routledge, https://doi. org/10.4324/9780203602263.

Oona Simolin on folkloristiikan väitöskirjatutkija Helsingin yliopistossa. 